\title{
Multi Insulin Sensitization with Tolerante to New Therapeutic Option: Degludec
}

Debora Nakatani Lopes*, Wilson Carlos Tartuce Aun, Joao Ferreira de Mello and Adriana Teixeira Rodrigues

Department of Allergy and Immunology, Hospital the State Public Server Sao Paulo-SP, Brasil

\begin{abstract}
Introduction: Insulin has been used for the treatment of diabetes mellitus (DM) since 1920. At first, the animal insulins were available for human use having frequent allergic reactions due to the differences in amino acid sequences with human insulin. Currently, with the use of human insulin, the prevalence of these reactions is around $2 \%$ and less than a third of these events were associated with insulin itself. These cases are associated with their additives or preservatives. The most commonly hypersensitivity reaction found is type I. In these cases, the use of a rapid-acting insulin is the best therapeutic alternative. We report the case of a multi-sensibilizated patient to insulin presenting tolerance to the ultralong-acting: Degludec insulin.

Case report: Female patient, 74, referring use of NPH (Neutral Protamine Hagedorn) human insulin for 5 years, with papule at the site of application of the insulin minutes after application. She visited the Allergy and Immunology Clinic of the State Public Servant Hospital of Sao Paulo referring anaphylaxis few minutes after application of human insulin (NPH). Also reported extensive local reaction due the use of detemir, and local reaction to lispro insulin. We conducted immediate skin test reading with insulins: Regular, Lispro, NPH, Detemir and Degludeca at a concentration of 1:1; addition of the additive (Protamine $10 \mathrm{mg} / \mathrm{ml}$ ) and latex. Presented positive test for all insulins, except Degludeca and presented negative test for protamine and latex.

Conclusion: we found no common additive to all insulins, which is not present in degludeca insulin (Tresiba $®$ ), enhancing insulin allergy hypothesis. Patient currently tolerates the use of long-acting insulin (Degludeca) and has adequate control of their blood sugar. In this case the patient had no insulin reaction prolonged action and this may be a new therapeutic option to be tested in patients with allergic reactions to insulin.
\end{abstract}

Keywords: Diagnosis; Drug hypersensitivity insulin; Insulin degludec; Insulin; Ultralente; Skin tests

\section{Introduction}

In January 1922, the first patient with diabetes mellitus (DM) received injection of bovine insulin pancreas, starting the "Insulin Age" and the success of therapy that immortalized its discoverers: Frederick Banting and Charles Best. Collip, chemist, worked in the extract preparation for clinical application. In 1923, Banting and Macleod won the Nobel Prize for Medicine and Physiology for the discovery of insulin [1].

Through crystallization, determining the structure of the amino acid sequence, long-acting insulins were made possible by the addition of zinc and protamine. In 1946, Krayenbuhl and Rosenberg developed the NPH (Neutral Protamine Hagedorn), with next action for 24 hours. But only in the 70s it is that insulins have undergone purification methods that led to the isolation of insulins practically free of other proteins, named as pro-insulin and peptide- $\mathrm{C}^{1}$.

In 1973 it was launched on the market an insulin preparation Porcine free of immunogenic peptides, called single component insulin [2]. With the advent of molecular biology and recombinant DNA, began the era of human biosynthetic insulins, used by many patients to the present day. Compared to animal insulin, human insulin has a different pharmacodynamics and pharmacokinetics. Human insulin tends to be more rapidly absorbed and to have a shorter period of action, but with a peak action that occur totally unpredictable way [3].

Previously, animal insulins were available for human use causing frequent allergic reactions due to amino acid sequence differences with human insulin. Currently, with the use of human insulin, the prevalence of these reactions is around $2 \%$ and less than a third of these events were associated with insulin itself. These cases are associated with their additives or preservatives including zinc, protamine, solvents (metacresol, glycerol, phenol, sodium phosphate etc.) [4,5].

Allergy may trigger from local symptoms to severe generalized allergic reactions. When IgE-mediated symptoms occur immediately after insulin administration (may present with redness and swelling at the injection site, to generalized reactions such as urticaria and angioedema). In rare severe cases, anaphylaxis with dyspnea and hypotension was observed [6].

The presence of insulin sensitization can be determined by skin tests and serum IgE specific levels [7]. We present the case of a patient who developed immediate hypersensitivity reaction to short and medium action insulin, but not with the prolonged. Similar cases have been reported previously in Japanese, Americans and Indians [8-10].

\section{Case Report}

ASM patient, female, 74 years old, physician, born and raised in

*Corresponding author: Debora Nakatani Lopes, Rua Doutor Diogo de Faria 1040 VI Clementino, CEP 04037004 Sao Paulo-SP, Brasil, Tel: 11948354059; E-mail: debora.nakatani@gmail.com

Received April 20, 2016; Accepted May 13, 2016; Published May 20, 2016

Citation: Lopes DN, Aun WCT, de Mello JF, Rodrigues AT (2016) Multi Insulin Sensitization with Tolerante to New Therapeutic Option: Degludec. J Diabetes Metab 7: 668. doi:10.4172/2155-6156.1000668

Copyright: $\odot 2016$ Lopes DN, et al. This is an open-access article distributed under the terms of the Creative Commons Attribution License, which permits unrestricted use, distribution, and reproduction in any medium, provided the original author and source are credited. 
Citation: Lopes DN, Aun WCT, de Mello JF, Rodrigues AT (2016) Multi Insulin Sensitization with Tolerante to New Therapeutic Option: Degludec. J Diabetes Metab 7: 668. doi:10.4172/2155-6156.1000668

Page 2 of 3

São Paulo-SP, diagnosed with hypertension and type 2 diabetes, was treated at the Allergy and Immunology clinic of the State Public Servant Hospital of São Paulo-SP.

Reported using NPH human insulin for 5 years, with wheal at the site of insulin injections minutes after application. 15 days ago, a few minutes after application of human insulin (NPH), she presented glottis edema, labial angioedema and urticaria disseminated. Once symptoms started, she used hydroxyzine, dexclorfeniramin and prednisolone at his residence and obtained improvement in symptoms, approximately 10 minutes after medication.

She also reported local reaction with lispro insulin (similar shortacting) and extensive local reaction due to the use of detemir insulin (similar long-acting), in an attempt to replace NPH insulin (they were prescribed after anaphylaxis event).

We conducted immediate skin test reading (Figure 1) with analogous human rapid-acting insulin (Regular Insulin and Lispro), NPH insulin and long-acting (Detemir and Degludeca) at a concentration of $1: 1$; addition of the additive (Protamine $10 \mathrm{mg} / \mathrm{ml}$ )

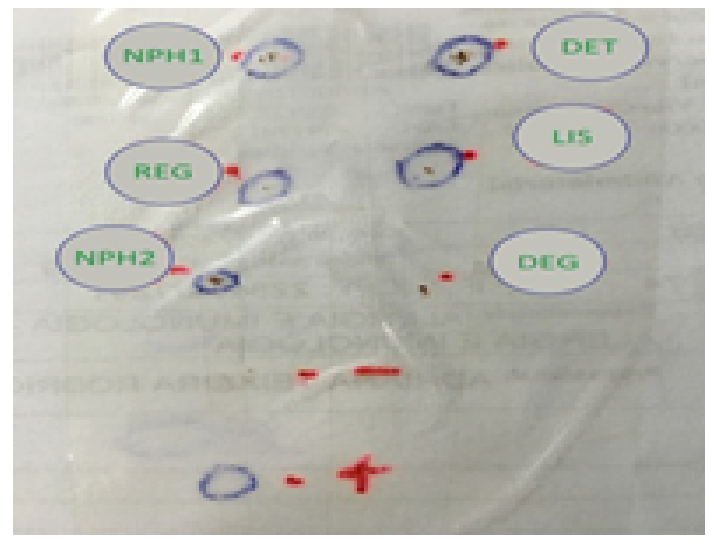

Figure 1: Decal prick test with insulins. NPH 1: Humulin $N \circledast$ (Lilly); REG: Novolin $₫ \mathrm{R}$ (Novo Nordisk); NPH 2: Novolin N $®$ (Novo Nordisk); DET: Levemir $\AA^{\circledR}$ (Novo Nordisk); LIS: Humalog ${ }^{\circledR}$ (Lilly); DEG: Tresiba ${ }^{\circledR}$ (Novo Nordisk); (-): Negative control (saline); (+): Positive control (histamine). and latex. Presented positive test for all insulins, except Degludeca and presented negative test for protamine and latex [11].

The specific IgE to search for human insulin by CAP- fluoresceinenzyme immunoassay method was $0.89 \mathrm{kU} / \mathrm{L}$.

\section{Discussion}

The allergy to insulin can be explained by the presence of a large amount of Langerhans cells in the epidermis, which act as antigenpresenting, performing transportation of foreign antigens and presenting to $\mathrm{T}$ cells in the regional lymph nodes, therefore increasing the antigenic components presentation of antigenic components of human insulin and mediate a localized immune response [12].

Human insulin is less immunogenic than animal insulin (porcine insulin is less immunogenic than bovine insulin). Bovine insulin differs from human insulin by three amino acids (two in the chain) and porcine insulin into one. When sensitization is limited to an origin of insulin or an additive, the allergen can be avoided by choosing a different preparation suitable for the patient [13].

The newly available degludec insulin is ultra-long acting basal insulin $\left(\right.$ Tresiba $^{\mathbb{R}}$ ), composed of a desB30 human insulin acylated at Lys B29 residue with a hexadecandioyl- $\gamma$-L-Glus side chain (Figure 2) [14].

Insulin has a high molecular weight, composed of multi-hexamers soluble and stable at the injection site, which upon subcutaneous injection occurs gradual diffusion of zinc from the ends of the multihexamers. As increasing zinc concentration in the depot injection, it will spread slowly, causing the uncoupling of the slow hexameter and gradually releasing monomers, which are then absorbed from the tank to the bloodstream, and thus a ultra-long term [14].

We analyzed the characteristics of the insulin used by the patient, but all had in common additives, including degludec (Table 1). With the result of the positive skin tests for insulin short and long action and the result of positive specific IgE sensitization to human insulin is proven.

The literature describes two allergy subtypes IgE mediated human insulin, i.e., a type showing the lack of responsiveness to insulin

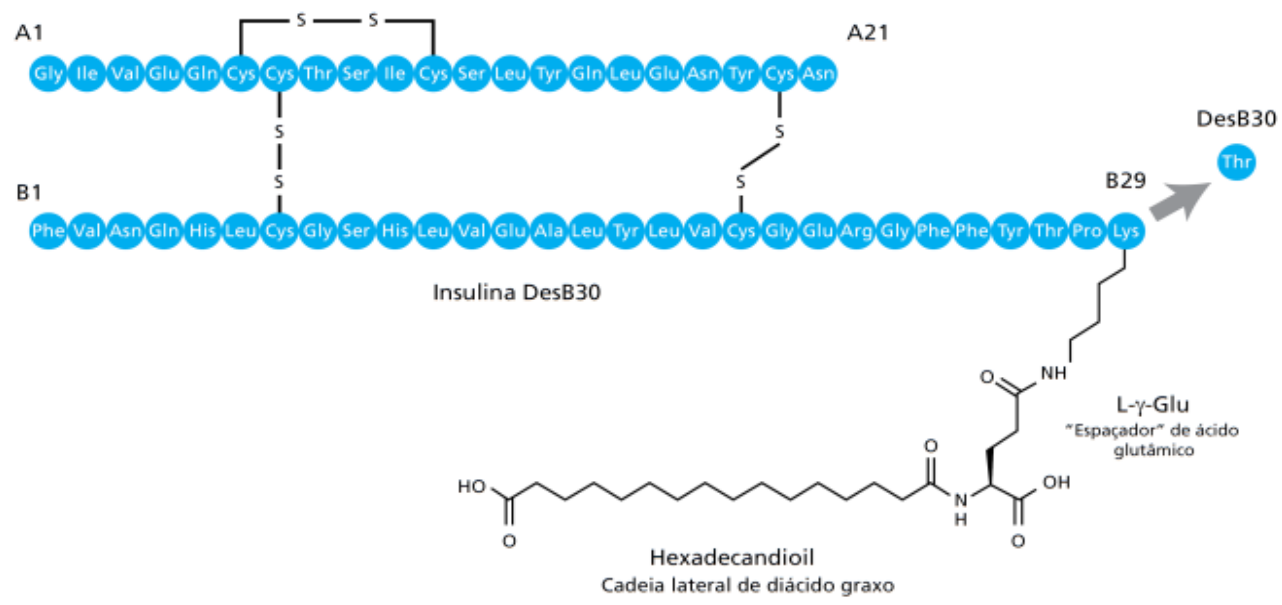

Figure 2: Structure of insulin degludeca [14]. 
Citation: Lopes DN, Aun WCT, de Mello JF, Rodrigues AT (2016) Multi Insulin Sensitization with Tolerante to New Therapeutic Option: Degludec. J Diabetes Metab 7: 668. doi:10.4172/2155-6156.1000668

Page 3 of 3

\begin{tabular}{|c|c|c|c|c|c|c|}
\hline & Regular & Lispro & Detemir & NPH 1 & NPH 2 & Degludec \\
\hline Zinc chloride & $x$ & & $x$ & & $x$ & $x$ \\
\hline Glycerol/Glycerin & $x$ & $x$ & $x$ & $x$ & $x$ & $x$ \\
\hline Metacresol & $x$ & $x$ & $x$ & $x$ & $x$ & $x$ \\
\hline Zinc oxide & & $x$ & & $x$ & & $x$ \\
\hline Dibasic sodium phosphate & & $x$ & & $x$ & & \\
\hline Disodium phosphate dihydrate & & & $x$ & & $x$ & \\
\hline Phenol & & & $x$ & $\mathrm{X}$ & $x$ & $x$ \\
\hline Sodium hydroxide & $x$ & $\mathrm{x}$ & $x$ & $\mathrm{x}$ & $x$ & $\mathrm{x}$ \\
\hline Hydrochloric acid & $x$ & $x$ & $x$ & $x$ & $x$ & $x$ \\
\hline Protamine sulfate & & & & $x$ & $x$ & \\
\hline Water for injection & $x$ & $x$ & $x$ & $x$ & $x$ & $\mathrm{x}$ \\
\hline Sodium chloride & & & $x$ & & & \\
\hline
\end{tabular}

Table 1: Additives used in insulin

analogues, including aspart and lispro insulin, and another type that responds to these insulin analogues, but not insulin long-acting insulin [8].

It can be assumed that the conformation and three dimensional structure of ultra-long-acting insulin molecule may mask its antigenicity, as after subcutaneous injection, a considerable amount of dimers are released from hexamers, divided into monomers (which is the active form of insulin). These dimers can be responsible for IgEmediated reactions. The long-acting insulin can release very slowly insulin monomers and may have less antigenicidade [15].

Other insulin allergy patients can safely use insulin analogues, as is the case of ultra-rapid insulins. Insulin lispro was designed by implementing B-28 amino acid residues and B-29, and aspart is produced by substituting the proline at position 28 in the insulin $\beta$ chain $[15,16]$. Since these chemical modifications involve dimerization site of the insulin molecule, are markedly reduced immunogenicity events. Since these analogues of human insulin have been used safely for some patients with allergy to human insulin $[16,17]$.

Even with the reduction of cases of allergy to insulin, there are reports in the literature. It is important that a good anamnesis be made, listing all the possible triggers so then we can make the best conduct, performing specific skin tests, specific IgE evaluation and looking to seek an alternative to the patient.

In this case, we can prove the multi-sensitization to human insulin and through specific tests could find a safe alternative to treatment, which was degludec insulin, which becomes a new alternative in the case of insulin sensitization.

\section{Conclusion}

Additives found in degludec insulin $\left(\right.$ Tresiba $\left.^{\circledR}\right)$, are also present in other insulins tested (short and long-acting) insulins such as: regular, $\mathrm{NPH}$, lispro and detemir, which enhances insulin allergy hypothesis. Patient has currently tolerating insulin ultra long-acting (DegludecTresiba $^{\mathbb{R}}$ ) with adequate glycemic control.

We note that this insulin can be evaluated in other cases of allergic reactions to insulin and may be a new therapeutic option.

\section{References}

1. Carrilho FM, Parreira JMB (1989) Insulinoterapia. Acta Medica Portuguesa Supl 1: 19-23.

2. Sonksen PH (1977) The evolution of insulin treatment. Clin Endocrinol Metab 6: 481-497.
3. Pires AC, Chacra AR (2008) A Evolucao da Insulinoterapia no Diabetes Melito Tipo 1. Arq Bras Endrocrinol Metab 52: 268-278.

4. Ghazavi MK, Johnston GA (2011) Insulin allergy. Clin Dermatol 29: 300-305.

5. Heinzerling L, Raile K, Rochlitz H, Zuberbier T, Worm M (2008) Insulin allergy: Clinical manifestations and management strategies. Allergy 63: 148-155.

6. Chng HH, Leong KP, Loh KC (1995) Primary systemic allergy to human insulin: recurrence of generalized urticaria after successful desensitization. Allergy 50 984-987.

7. Lee AY, Chey WY, Choi J, Jeon JS (2002) Insulin-induced drug eruptions and reliability of skin tests. Acta Derm Venereol 82: 114 - 117.

8. Adachi A, Fukunaga A, Horikawa T (2004) A case of human insulin allergy induced by short-acting and intermediate-acting insulin but not by long-acting insulin. Int J Dermatol 43: 597-599.

9. Kara C, Kutlu AO, Evliyaoglu O, Bilgili H, Yildirim N (2005) Successful treatment of insulin allergy in a 1-year-old infant with neonatal diabetes by lispro and glargine insulin. Diabetes Care 28: 983-984.

10. Belhekar MN, Pai S, Tayade P, Dalwadi P, Munshi R, et al. (2015) A case of hypersensitivity to soluble and isophane insulins but not to insulin glargine. Indian Journal of Pharmacology 47: 227-229.

11. Rodrigues AT, Ensina LFC, Garro LS, Tanno LC, Giavina-Bianchi P, et al. (2010) Human insulin allergy: four case reports. EurAnn Allergy Clinlmmunol 42: 221-223.

12. Cumberbatch M, Dearman RJ, Griffiths CE, Kimber I (2003) Epidermal Langerhans cell migration and sensitisation to chemical allergens. APMIS 111 797-804.

13. Kahn CR, Rosenthal AS (1979) Immunologic reactions to insulin: insulin allergy, insulin resistance, and the autoimmune insulin syndrome. Diabetes Care 2: 283-295.

14. Jonassen I, Havelund S, Hoeg-Jensen T, Steensgaard DB, Wahlund PO, et al. (2012) Design of the novel protraction mechanism of insulin degludec, an ultralong-acting basal insulin. Pharm Res 29: 2104-2114.

15. Kang S, Brange J, Burch A, Volund A, Owens DR (1991) Subcutaneous insulin absorption explained by insulin's phycochemical properties. Evidence from absorption studies of soluble human insulin and insulin analogues in humans. Diabetes Care 14: 942-948.

16. Kumar D (1997) Lispro analog for treatment of generalized allergy to human insulin. Diabetes Care 20: 1357-1359.

17. Airaghi L, Lorini M, Tedeschi A (2001) The insulin analog aspart: a safe alternative insulin allergy. Diabetes Care 24: 2000. 